\title{
Pengembangan Aplikasi Sipamsimas (Sistem Informasi Penyedia Air Minum dan Sanitasi Masyarakat) di BUMDes "Sumber Rejeki" Desa Cagakagung Kecamatan Cerme Kabupaten Gresik
}

\author{
Alfi Nugroho ${ }^{1}$, Trisa Indrawati ${ }^{2}$, Surya Priyambudi ${ }^{3}$ \\ ${ }^{1}$ Fakultas Teknik, Universitas Wijaya Putra, Surabaya, Indonesia \\ ${ }^{2}$ Fakultas Ekonomi, Universitas Wijaya Putra, Surabaya, Indonesia \\ ${ }^{3}$ Fakultas Bahasa dan Satra, Universitas Wijaya Putra, Surabaya, Indonesia \\ E-mail: alfinugroho@uwp.ac.id, trisaindrawati@uwp.ac.id, surya@uwp.ac.id
}

\begin{abstract}
Abstrak
BUMDes "Sumber Rejeki" adalah Penyediaan Air Minum dan Sanitasi berbasis Masyarakat (PAMSIMAS), Permasalahan yang dihadapi mitra adalah manajemen BUMDes masih sangat sederhana, belum bisa menghitung Harga Pokok Produksi, Proses pencatatan meter air masih manual dan penghitungan dan pembuatan slip tagihan masih menggunakan Microsoft Excel dan Belum memiliki komputer, Solusi yang ditawarkan adalah dengan mengadakan Pelatihan manajemen keuangan terutama dalam menghitung Harga Pokok Produksi dan Penjualan, Pengembangan program komputer berbasis website dan android untuk pengelolaan PAMSIMAS, Pengadaan Komputer dan Printer sesuai spesifikasi yang dibutuhkan, Pelatihan komputer dan pengoperasian program komputer berbasis website dan android. Metode pelaksanaan program ini berupa tahapan pelaksanaan program untuk menjalankan solusi yang ditawarkan dan menyelesaikan masalah, yaitu; Rapat awal dan Koordinasi dengan mitra; Menyusun program dan jadwal kegiatan, pengadaan komputer dan printer; Pengembangan Program Komputer meliputi: Pengadaan program komputer untuk aneka jasa layanan/pembayaran, pelatihan dan pendampingan pengelolaan usaha, Mengembangkan program komputer berbasis website dan Android untuk pengelolaan PAMSIMAS; sedangkan Program Pelatihan dan Pendampingan, meliputi: Pelatihan dan Pendampingan PAMSIMAS, Microsoft Office dan Aneka Jasa Pembayaran; dalam aspek Budaya organisasi, Penataan SDM, Penghitungan harga pokok produksi dan harga pokok penjualan, dan Musyawarah dan sosialisasi dengan perangkat desa. Tahapan akhir adalah pengukuran ketercapaian target luaran; evaluasi dan Rencana Keberlanjutan.
\end{abstract}

Kata Kunci: BUMDes, aplikasi pengelolaan PAMSIMAS, aneka jasa pembayaran

\section{PENDAHULUAN}

Mitra dan Program Kemitraan Masyarakat ini adalah BUMDes "Sumber Rejeki" dengan usaha awal yang dijalankan oleh BUMDes "Sumber Rejeki" adalah Penyediaan Air Minum dan Sanitasi berbasis Masyarakat (PAMSIMAS), Pengelolaan Sampah dan Pembayaran Listrik Pascabayar.

Salah satu potensi yang ada di Desa Cagakagung adalah tersedia 2 buah sumur galian dengan debit air yang cukup besar. Sumur ini sudah ada sejak jaman Belanda, namun terakhir di perbaiki pada tahun 1976 melalui Program Operasi Sitarda oleh ABRI/TNI Masuk Desa. Dengan menggunakan Dana Desa, pada awal tahun 2015, dibangun tandon air dan disalurkan kepada 75 rumah di sisi utara desa, karena di sisi utara belum ada yang memiliki sumur bor, karena tidak adanya sumber air

Teknologi Informasi dan Telekomunikasi 


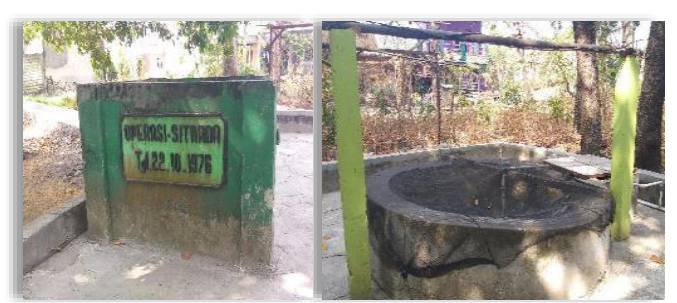

Gambar 1 Sumur Kidul sebagai bahan baku PAMSIMAS

Pada tahun 2017, melalui program Penyediaan Air Minum dan Sanitasi bagi Masyarakat (PAMSIMAS) dari Pemerintah Kabupaten Gresik dan didukung dengan Dana Desa, dibuatkan tandon baru dengan kapasitas 6000 liter dan pemasangan instalasi pipa induk dan sambungan rumah (SR) secara bertahap. Saat ini PAMSIMAS sudah mampu mengaliri 488 sambungan rumah di 2 Dusun yaitu Dusun Cagak dan Dusun Agung

Struktur organisasi BUMDes hanya terdiri dari Ketua, Sekretaris dan Bendahara. Pengurus yang saat ini ada 3 orang yaitu Ketua, Sekretaris dan Bendahara, dibantu dengan 11 petugas lapangan yang merupakan Ketua RT sebagai pencatat meter, penagihan, pengawas dan pemeliharaan. Sistem pengupahan Pengurus juga masih sangat sederhana, besaran upah ditentukan $10 \%$ dari pembayaran yang diterima dari masingmasing RT.

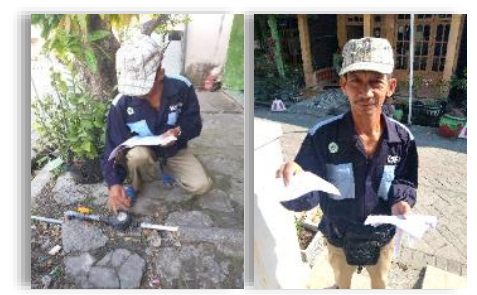

Gambar 1 Petugas Pencatat Meter dan Penyerahan Slip Tagihan Air

Permasalahan mitra di bidang Manajemen, yaitu; 1) Manajemen BUMDes masih sangat sederhana, struktur organisasi BUMDes hanya terdiri dari Ketua, Sekretaris dan Bendahara dan belum memiliki pegawai tetap yang mengelola usaha; 2) Pengurus saat ini masih belum bisa menghitung Harga Pokok Produksi, sehingga harga jual terlalu murah ke warga; 3) Proses pencatatan meter listrik masih manual dan penghitungan dan pembuatan slip tagihan masih menggunakan Microsoft Excel melalui jasa pihak lain; 4) Belum memiliki komputer, penghitungan tagihan air, laporan keuangan dan slip pembayaran masih rental atau ke jasa pengetikan. Pengurus BUMDes pun tidak bisa mengoperasikan komputer.

Tabel 1 Harga Distribusi Air PAMSIMAS 2019

\begin{tabular}{cllr}
\hline No & \multicolumn{1}{c}{ Uraian } & \multicolumn{2}{c}{ Harga /M3 } \\
\hline 1 & Harga dasar/abonemen & Rp. & $0,-$ \\
\hline 2 & Rumah Tangga / Kos-kosan & Rp. & $1.500,-$ \\
\hline 3 & Industri Kecil & Rp. & $2.000,-$ \\
\hline
\end{tabular}

Sumber : Data diolah [3]

Solusi di bidang Manajemen; 1) Perbaikan pembagian beban kerja pengurus, 2) Pelatihan manajemen keuangan terutama dalam menghitung Harga Pokok Produksi dan Penjualan; 3) Pengembangan program komputer berbasis website dan android untuk pengelolaan PAMSIMAS; 4) Pengadaan Komputer dan Printer sesuai spesifikasi yang dibutuhkan; 5) Pelatihan komputer dan pengoperasian program komputer berbasis website dan android; dan 6) Pelatihan pengoperasian program komputer aneka jasa pembayaran yang akan dikembangkan tahapan pelaksanaan program untuk menjalankan solusi yang ditawarkan dan menyelesaikan masalah, yaitu; Rapat awal tim pelaksana dan Koordinasi dengan mitra; Menyusun program dan jadwal kegiatan, Pengadaan dan Pemeliharaan, meliputi: Pengadaan dan instalasi pompa air, perbaikan instalasi, pembuatan bak kontrol dan filter air, pengadaan perabot kantor, pengadaan komputer dan printer; Pengembangan Program Komputer dan Pengembangan Usaha, meliputi: Pengadaan program komputer untuk aneka jasa layanan/pembayaran, Kerjasama dengan Bank BRI, sosialisasi kepada masyarakatMengembangkan program komputer berbasis website dan Android untuk pengelolaan PAMSIMAS; dan Program Pelatihan dan Pendampingan, meliputi: Pelatihan dan Pendampingan Pemeliharaan Pamsimas; Program \begin{tabular}{l|l} 
Teknologi Informasi dan Telekomunikasi & 26
\end{tabular} 
komputer: PAMSIMAS, Microsoft Office dan Aneka Jasa Pembayaran; Budaya organisasi, Penataan SDM, Penghitungan harga pokok produksi dan harga pokok penjualan, dan Musyawarah dan sosialisasi dengan perangkat desa dan BPD

\section{METODE}

Berdasarkan analisis situasi dan rencana kerja yang dilakukan, maka ada perlu perioritas terahadap permasalahan yang di hadapi oleh mitra. Dari hasil pengamatan yang dilakukan oleh tim permasalahan mitra antaralain,

1)dalam bidang manajemen 2)perhitungan harga pokok 3)proses pencatatan meter dan perhitungan pembuatan slip 4)pengadaan komputer dan perabot kantor

Berdasarkan permasalahan mitra di atas, tentu permasalahan yang di hadapi perlu di berikan penyelesaian. Untuk itu solusi yang di tawarkan oleh tim adalah pemberian buku literatur tanaman hias dan pelaksanaan pelatihan pembukuan sederhana.

Tabel.2 Metode Pelaksanaan

\begin{tabular}{|c|c|c|}
\hline masalah & Solusi & $\begin{array}{l}\text { Metode } \\
\text { Pelaksanaan }\end{array}$ \\
\hline \multirow[t]{2}{*}{$\begin{array}{l}\text { dalam } \\
\text { bidang } \\
\text { manajemen }\end{array}$} & $\begin{array}{l}\text { Perbaikan } \\
\text { pembagian } \\
\text { beban kerja } \\
\text { pengurus }\end{array}$ & $\begin{array}{l}\text { Pendampingan } \\
\text { penataan SDM }\end{array}$ \\
\hline & $\begin{array}{l}\text { Pengangkatan } \\
\text { pegawai baru } \\
\text { untuk } \\
\text { menangani } \\
\text { administrasi } \\
\text { PAMSIMAS }\end{array}$ & $\begin{array}{l}\text { Rekrutmen } \\
\text { pegawai baru dari } \\
\text { masyarakat } \\
\text { setempat dan } \\
\text { pelatihan }\end{array}$ \\
\hline \multirow[t]{2}{*}{$\begin{array}{l}\text { perhitungan } \\
\text { harga pokok }\end{array}$} & $\begin{array}{l}\text { Pelatihan } \\
\text { manajemen } \\
\text { keuangan }\end{array}$ & $\begin{array}{l}\text { Pelatihan } \\
\text { penghitungan } \\
\text { harga pokok } \\
\text { produksi dan } \\
\text { harga pokok } \\
\text { penjualan }\end{array}$ \\
\hline & & $\begin{array}{l}\text { Musyawarah dan } \\
\text { sosialisasi } \\
\text { penyesuaian } \\
\text { harga layanan }\end{array}$ \\
\hline
\end{tabular}

\begin{tabular}{lll}
\hline masalah & Solusi & $\begin{array}{l}\text { Metode } \\
\text { Pelaksanaan }\end{array}$ \\
\hline & PAMSIMAS
\end{tabular}

\begin{tabular}{|c|c|c|}
\hline $\begin{array}{l}\text { proses } \\
\text { pencatatan } \\
\text { meter air } \\
\text { dan } \\
\text { perhitungan } \\
\text { pembuatan } \\
\text { slip }\end{array}$ & $\begin{array}{l}\text { Pengembangan } \\
\text { program } \\
\text { komputer }\end{array}$ & $\begin{array}{l}\text { Mengembangkan } \\
\text { program } \\
\text { komputer } \\
\text { berbasis website } \\
\text { dan Android } \\
\text { untuk } \\
\text { pengelolaan } \\
\text { PAMSIMAS }\end{array}$ \\
\hline \multirow[t]{2}{*}{$\begin{array}{l}\text { pengadaan } \\
\text { komputer } \\
\text { dan perabot } \\
\text { kantor }\end{array}$} & $\begin{array}{l}\text { Pengadaan } \\
\text { Komputer dan } \\
\text { Printer sesuai } \\
\text { spesifikasi yang } \\
\text { dibutuhkan }\end{array}$ & $\begin{array}{l}\text { Pengadaan } \\
\text { komputer dan } \\
\text { printer }\end{array}$ \\
\hline & $\begin{array}{l}\text { Pelatihan } \\
\text { komputer dan } \\
\text { pengoperasian } \\
\text { program } \\
\text { komputer }\end{array}$ & $\begin{array}{l}\text { Pelatihan dan } \\
\text { pendampingan } \\
\text { pengoperasian } \\
\text { komputer dan } \\
\text { program } \\
\text { Microsoft Office }\end{array}$ \\
\hline
\end{tabular}

\section{HASIL DAN PEMBAHASAN}

Adapun hasil dari pengabdian kepada masyarakat ini dapat di jelaskan sebagai berikut.

1) Dalam bidang manajemen, sudah dilakukan pendampingan penataan SDM dengan struktur pengurus baru yang berisi ketua, sekretaris, bendahara, operator dan penanggung jawab; 2) dalam perhitungan harga pokok, pencatatan meter air dan pembuatan slip tagihan sudah menggunakan aplikasi yang di kembangkan oleh tim berbasis aplikasi komputer (web base) "SiPamsimas" yang dapat di akses di alamat http://sipamsimas.id/login dan aplikasi android untuk pencatat meter

Teknologi Informasi dan Telekomunikasi 


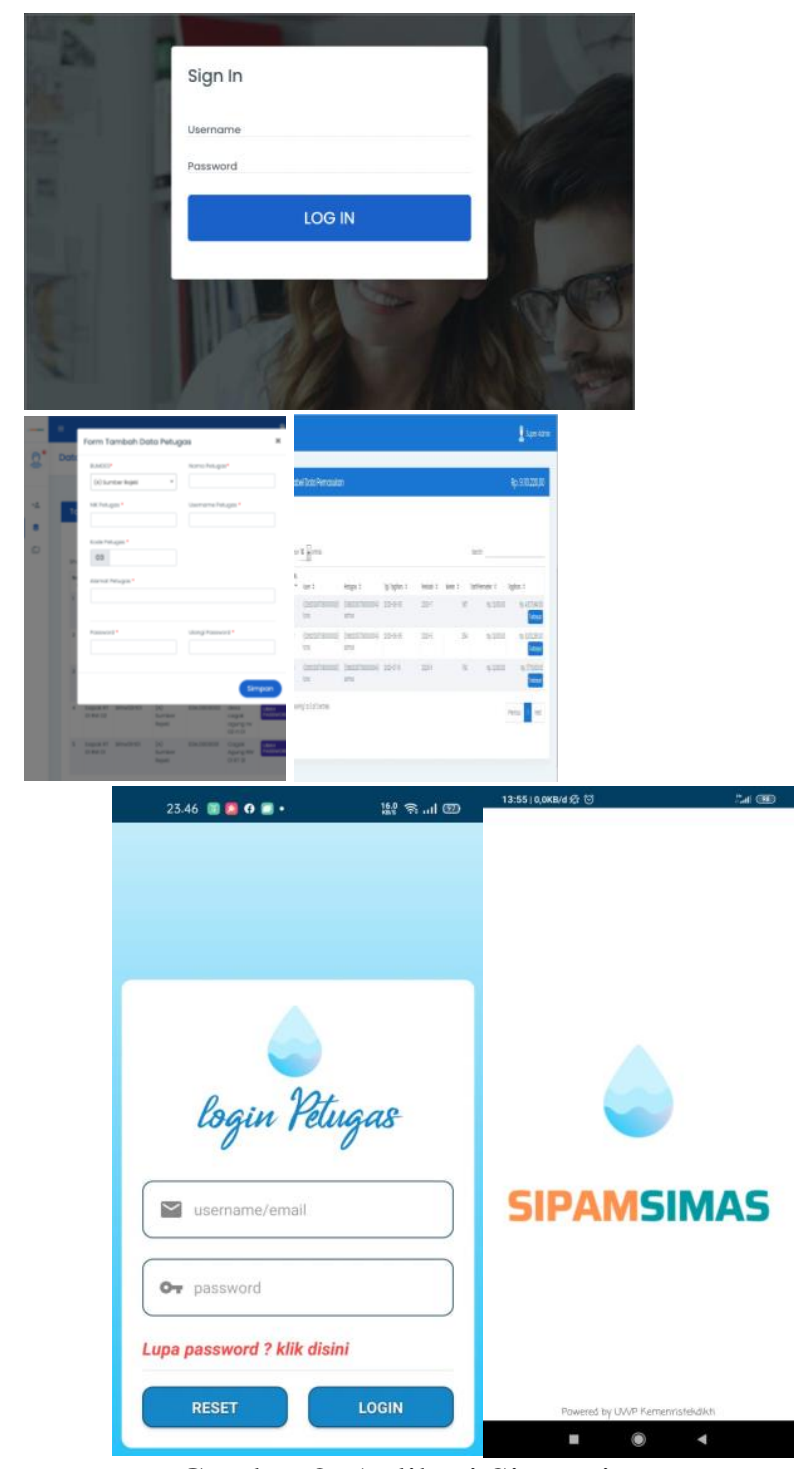

Gambar 2. Aplikasi Sipamsimas

Dalam penggunaan aplikasi SiPamsimas telah dilakukan pelatihan dan pendampingan beberapa kali, baik dengan pengurus BUMDes ataupun kepada petugas pencatcat meter, hal tersebut sangat di sambut baik oleh pengurus BUMDes dikarenakan kemudahan dalam pengoperasian dan mempermudah dalam mencetak slip tagihan.

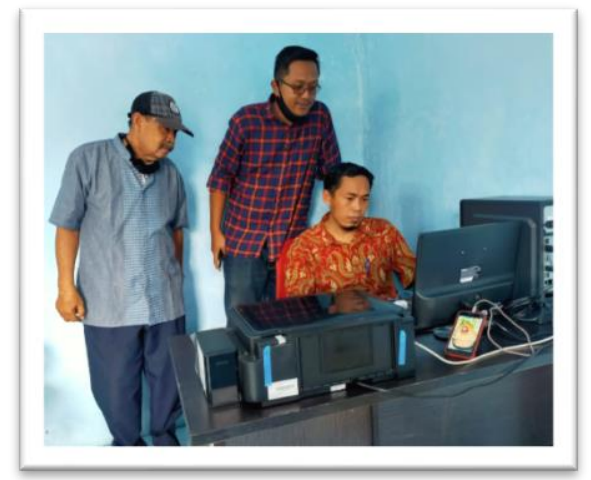

Gambar 3 Pelatihan pengoperasian Aplikasi SiPamsimas kepada pengurus BUMDes

3) pengadaan komputer dan perabot kantor dilaksanakan serah terima kepada pengurus BUMDes dan kepala Desa Cagak agung

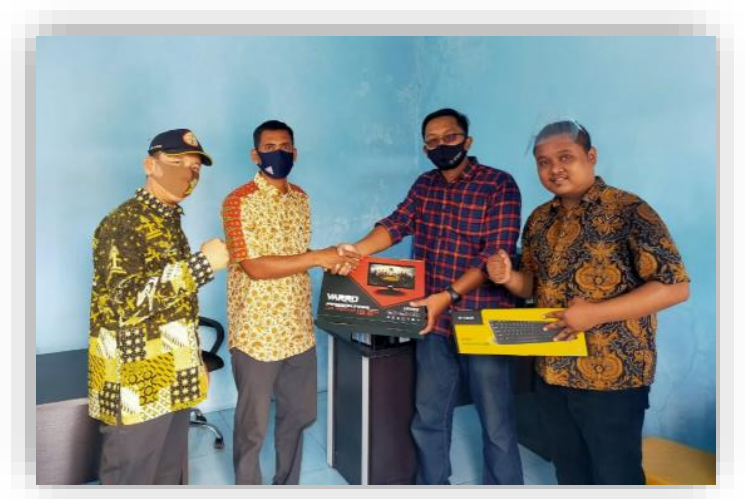

Gambar 4 serah terima perabot kantor

\section{KESIMPULAN}

Setelah Pelaksanaan Pengabdian Masyarakat maka dapat disimpulkan Sebagai berikut:: (1)Keterbukaan pengurus BUMDes dan Perangkat desa dalam menyikapi permasalahan yang muncul dalam pelaksanaan Program pengabdian kepada masyarakat, (2)Keinginan untuk memajukan SDM mayarakat sangat tinggi,(3) Dari pengurus BUMDes sangat terbuka dengan adanya aplikasi PAMSIMAS yang berbasis website dan android. 


\section{UCAPAN TERIMAKASIH}

Ucapan terima kasih disampaikan kepada Universitas Wijaya Putra dan Kementrian Pendidikan dan Kebudayaan yang telah memberikan kesempatan kepada penulis untuk melakukan pengabdian kepada masyarakat di BUMDes Sumber rejeki di Desa Cagak Agung Kabupaten Gresik.

\section{REFERENSI}

Subanar, (1992). Permasalahan Usaha Kecil Menengah. Surabaya: Dinas/Kanwil Perindustrian Jawa Timur.
Fandy Tjiptono, Ph,D. 2011. "Pemasaran Jasa". Bayu media.

Bank Indonesia. 2015. Pedoman Pencatatan Transaksi Keuangan Usaha Kecil Badan Usaha Bukan Badan Hukum Sektor Manufaktur. Departemen Pengembangan UMKM Bank Indonesia. Jakarta 